\title{
Synopsis of Boraginaceae sensu lato in the Caatingas of the São Francisco River, Northeastern Brazil
}

\author{
José Iranildo Miranda de Melo* \\ Universidade Estadual da Paraíba, Centro de Ciências de Biológicas e da Saúde, Departamento de Biologia, Avenida das \\ Baraúnas, 351 - Bairro Universitário, 58429-500, Campina Grande, Paraíba, Brazil \\ tournefort@gmail.com
}

\begin{abstract}
Melo, J.I.M. 2015. Synopsis of Boraginaceae sensu lato in the Caatingas of the São Francisco River, Northeastern Brazil. Anales Jard. Bot. Madrid 72(1): e013

This work presents a commented synopsis of Boraginaceae sensu lato in the basin of the lower-middle and lower stretches of the São Francisco River in Northeast Brazil (states of Pernambuco and Bahia). Five genera and 21 species were recorded: Euploca, with six species; Cordia, with five; Varronia, with four; and Heliotropium and Myriopus, represented by three species each. A new combination in the genus Myriopus is here proposed. Keys for the separation of genera and species as well as distributional and geographical data are provided.
\end{abstract}

Keywords: Brazilian flora, caatinga, Lamiids, floristics, northeastern.

\section{INTRODUCTION}

Boraginaceae is an important angiosperm family distributed worldwide that includes herbs, subshrubs, shrubs, trees, or less frequently, lianas. Fruit characters are important for generic and specific delimitation (Candolle, 1845; Fresenius, 1857-1863; Bentham \& Höoker, 1873-1876; Gürke, 1893; Johnston, 1928; 1930; Förther, 1998).

The first formal taxonomic treatment was published by Candolle (1845) who recognized 17 genera to the family. Classic works that covered the family as a whole include Bentham and Hooker (1873-1876), who distinguished 68 genera; Gürke (1893), who was the first author to divide the family into four subfamilies (Boraginoideae, Cordioideae, Ehretioideae and Heliotropioideae) and 21 genera; and Dalla Torre and Harms (1900) who followed the classification of Gürke (1893). Later on, the family was studied in different regions of the world, particularly in South America, and the works of Johnston $(1928,1930)$ amongst others expanded the knowledge of the taxonomy and geographical distribution of Boraginaceae s.l., especially of Cordia, Heliotropium and Tournefortia in this region. In Brazil, the most comprehensive treatment of Boraginaceae is still the monograph of the Flora Brasiliensis by Fresenius (1857-1863), which recognized nine genera.

According to Judd \& al. (1999), Boraginaceae belongs to the order Solanales. However, according to Angiosperm Phylogeny Group (1998) and Angiosperm Phylogeny Group II (2003), Albach \& al. (2001), Bremer \& al. (2002) and Soltis \& al. (2002), this family shows an uncertain position and therefore should not be included in an order with other families but rather constitute one on its own (Boraginales), as suggested by Böhle \& Hilger (1997) and Gottschling \& al. (2001). However based in molecular phylogenetic studies,

\section{Resumen}

Melo, J.I.M. 2015. Sinopsis de Boraginaceae sensu lato de las Caatingas del río São Francisco, nordeste del Brasil. Anales Jard. Bot. Madrid 72(1): e013

Este trabajo presenta una sinopsis comentada de la familia Boraginaceae sensu lato en la cuenca media y baja del río São Francisco, nordeste del Brasil (estados de Pernambuco y Bahía). Se reconocen cinco géneros y 21 especies: Euploca, con seis especies; Cordia, con cinco; Varronia, con cuatro y Heliotropium y Myriopus, representados por tres especies cada. Se propone una combinación nueva en el género Myriopus. Así mismo, se aportan claves para la separación de los géneros y especies y datos sobre la distribución geográfica y la ecología de las especies.

Palabras clave: flora brasileña, Caatinga, Lamiídeas, florística, nordeste.

according to the Angiosperm Phylogeny Group III (2009), Boraginaceae is placed in the core of Eudicotyledons, Euasterids I, within the Lamiids.

Studies using phylogenetic analyses using chloroplast DNA have been carried out by Böhle \& Hilger (1997) who proposed raising the taxonomic rank of the five subfamilies to the family level: Boraginaceae, Cordiaceae, Ehretiaceae, Heliotropiaceae and Wellstediaceae. More recently various studies including both phylogenetics and taxonomic approaches were conducted on different groups belonging to neotropical Boraginales: Diane \& al. (2002a), Hilger \& Diane (2003), Gottschling \& al. (2005), Luebert \& Wen (2008), Luebert \& al. (2011a, 2011b), Luebert (2013), and Luebert \& Hilger (2014).

The current state of knowledge of the representativeness of Boraginaceae sensu lato, together with the biogeographic importance of the São Francisco River basin and the ecological interest of the Caatinga domain, suggests that a floristic update of that area may be useful. Thus a commented synopsis of the representatives of this family occurring in Northeastern Brazil, along the states of Pernambuco and Bahia, is presented, aiming to provide information on biogeographic aspects, and to a lesser extent in taxonomic aspects, including one new combination in the genus Myriopus Small.

\section{MATERIAL AND METHODS}

\section{Study Area}

The São Francisco River source is in Serra da Canastra in the state of Minas Gerais, at an altitude of $1600 \mathrm{~m}$. It runs some $2700 \mathrm{~km}$ to the northeast, covering a large part of this

\footnotetext{
* Corresponding author.
} 
region, and has a great regional importance from an ecological, economical and social perspective. The hydrographical basin of the São Francisco River covers approximately $640,000 \mathrm{~km}^{2}$, extending over regions with humid, semiarid and arid climates. The basin is divided into four regions: Upper São Francisco, from the source to Pirapora, Minas Gerais state; Middle São Francisco, between Pirapora and Remanso, Bahia state; Lower-middle São Francisco, from Remanso to Cachoeira de Paulo Afonso and, Lower São Francisco, from Paulo Afonso, Bahia state, to the mouth, at the Atlantic Ocean. Many tributaries of the São Francisco River are permanent, as is the São Francisco itself (Fig. 1). The lower São Francisco basin is under a humid climate but it has tributaries that come from the semiarid and its vegetation is predominantly Cerrado and Atlantic Forest (Frigoletto, 2011).

\section{Synopsis preparation}

Comparative morphological analyses were conducted at the Botany Laboratory of the Department of Biology, Campus I, at the State University of Paraíba (UEPB) based on specimens deposited in the herbaria HVASF (Federal University of Vale do São Francisco foundation) and CPATSA (Brazilian Agricultural Research Corporation Semiarid), both located in the municipality of Petrolina, Pernambuco, Brazil. For the identification of the genera and species, local and regional flora and taxonomic revisions (Taroda \& Gibbs, 1986a; 1986b; 1987; Förther, 1998) were consulted, in addition to the classic studies (Gürke, 1893; Johnston, 1928; 1930). The studies of Melo \& Sales (2004, 2005), Melo \& LyraLemos (2008), Melo \& Semir (2008, 2010) and Cavalheiro $\&$ al. (2011) were also used. The vegetative and reproductive structures were characterized according to the works of Hickey (1973), Radford \& al. (1974), Rizzini (1977) and Payne (1978). Author names of genera and species were verified in the Missouri Botanical Garden database $\left(\mathrm{W}^{3}\right.$ Tropicos, 2014) and in the Species List of Brazilian Flora online (Melo \& al., 2014). Identification keys for separation of genera and species have been provided, and data on the distribution of the species are presented. The geographic distribution of the species was verified in Melo \& al. (2010, 2014) and the ecological distribution was based on the specific literature cited above and specimens obtained in field works or examined in Brazilian herbaria (ASE, CPATSA, EAN, HST, HUEFS, HVASF, JPB, MOSS, PEUFR, UFC, UFG, UFP, UnB, R, RB). The herbaria abbreviations follow Thiers (2012).

\section{COMMENTED SYNOPSIS}

Boraginaceae Juss., Gen. Pl.: 128. 1789; nom. cons.

Trees, shrubs, subshrubs, lianas or herbs. Leaves alternate, subopposite or falsely opposite, simple, exstipulate; petiolate or sessile; leaf blade entire. Inflorescence terminal, falsely terminal, axillary or internodal, scorpioid cymes, spikes, capitate, panicles or thyrsoid, lax or congested. Flowers presenting bracts or no; corolla salverform, tubular, tubular-salverform, tubular-campanulate or obcampanulate, cream, lilac or white, throat of corolla generally yellow. Stamens five, included or excluded, with anthers free or coherent at the apex, with or without appendices, presenting longitudinal dehiscence. Ovary superior, 2 or 4-locular by the intrusion of a false septum; ovules 1-2 per locule, anatropous or hemi-anatropous; placentation axillary or basal. Style entire or 2-bifurcate, terminal, cylindrical or subcylindrical. Stigma sessile, subsessile or with evident style. Fruits dry or fleshy, dehiscent or indehiscent, drupaceous

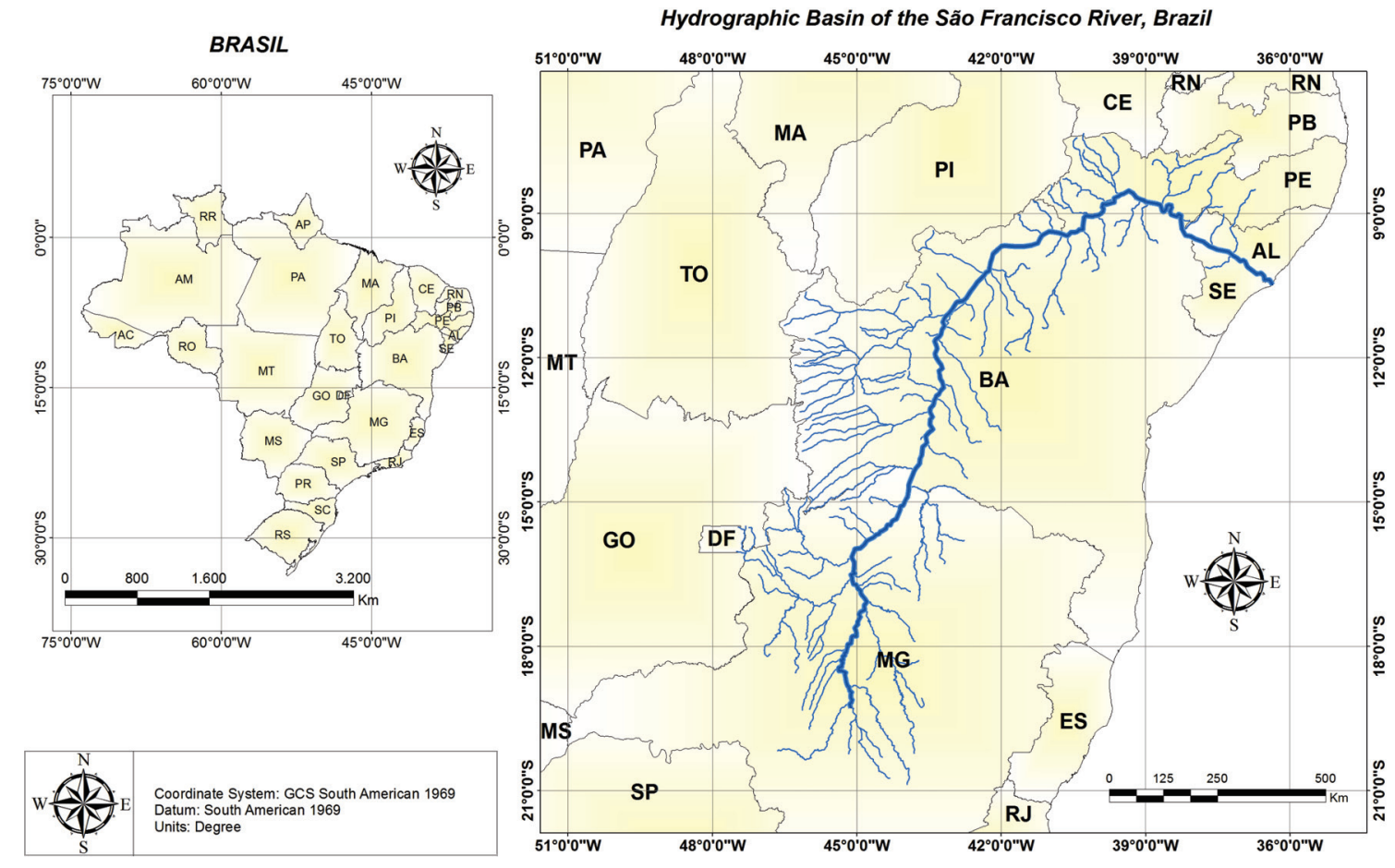

Fig. 1. Location of the São Francisco River and their tributaries, Brazil (map prepared by Jean P. Costa and Manoel Jeovani P. Costa). 
sometimes pyrenes or schizocarpous with 2 or 4 nutlets. $1-2$ seeds per locule; plane or curved embryo.

The genera Euploca and Myriopus were recently reestablished. Euploca includes the species belonging to Heliotropium sect. Orthostachys R. Br. and the genera Hilgeria Förther and Scbleidenia Endl. and is defined by the following morphological and anatomical data: mericarpid or endocarpids structures with surface sculpturing described as "pits" (Diane \& al., 2002a), kranz-chlorenchyma organization in leaves of almost all species, and the exclusive occurrence of characteristic trichomes that are on a pedestal of distinctly enlarged foliar epidermis cells (Diane \& al., 2003). The recognition of the genus Myriopus is based on suggestions by Diane \& al. (2002a) and includes the species circumscribed to Tournefortia sect. Cyphocyema I.M. Johnst. (Johnston, 1930). These are lianas with the following features: drupaceous deeply 4-lobed fruits with one seeded and 4-layered endocarpids, a thick tissue of transfer cells in the placenta region (Diane \& al., 2002b), characteristic flowers with subulate corolla lobes and inflated bases of the corolla tubes, and involute corolla margins in the buds (Diane \& al., 2003).

\section{Representativeness and ecological distribution}

In the studied area, five genera and 21 species were recorded: Cordia and Euploca, with five species each; Varronia, with four species and the genera Heliotropium and Myriopus represented by three species each. In the states of Bahia and Pernambuco, 13 and 14 species were found respectively, four of them occurring on both states (C. trichotoma, E. paradoxa, H. elongatum and V. leucocephala). Although these species have already been recorded for the flora of caatingas of the São Francisco River, comments on its geographical and ecological distribution are presented in this work.

The species reported are herbs (E. barbata, E. paradoxa, E. polyphylla, $H$. angiospermum, $H$. curassavicum and $H$. elongatum), subshrubs (E. fruticosa, E. procumbens, E. ternata, $H$. angiospermum and $H$. elongatum), shrubs (C. glabrata, $V$. curassavica, V. globosa, V. leucocephala and V. leucomalloides), trees (C. glazioviana, C. incognita, C. rufescens and C. trichotoma) or lianas (M. rubicundus, M. salzmannii and M. villosus), and they are predominantly associated to open areas in sandy and clayed soils or rarely in saline soils (H. curassavicum) or sandy banks (E. paradoxa) in low-altitudes, generally in disturbed areas by the anthropogenic action.

However, some of these species have a wide ecological amplitude, e.g., E. polyphylla and E. procumbens are distributed in Brazil from the coastal line (Atlantic Ocean) to the semiarid region (Caatinga vegetation) and this same distribution pattern is found in Heliotropium angiospermum, $H$. elongatum and two Myriopus species (M. rubicundus and M. villosus). Myriopus salzmannii is found principally in areas of Caatinga vegetation. In Brazil, Cordia glazioviana, C. incognita and E. barbata are restricted to the Caatinga, C. incognita and E. barbata being endemic to this vegetation type. Regarding the Varronia species, V. curassavica, $V$. globosa and $V$. leucocephala are associated predominantly to open areas at the Caatinga vegetation while $V$. leucomalloides occurs also in open areas on Caatinga and Cerrado vegetation, only known to Brazil.

\section{Key to the genera}

1. Style bifid presenting 4 stigmatic branches; inflorescences never scorpioid .................................................. 2

1. Style entire presenting undivided stigma; inflorescences scorpioid cymes, sometimes with secundiflorous branches Cordia

2. Inflorescences panicle or thyrsoid Varronia

2. Inflorescences spike or capitate

3. Fruit drupaceous with 4 lobes Myriopus

3. Fruit schizocarpous with 2 or 4 nutlets

4. Inflorescences ebracteate; anthers free; fruits with 2 nutlets Heliotropium

4. Inflorescences generally bracteate; anthers coherent; fruits with 4 nutlets

Euploca

Cordia L., Sp. Pl. 1: 190. 1753.

\section{Key to the species}

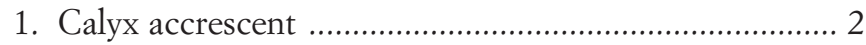

1. Calyx never accrescent .................................................. 3

2. Drupes acuminate ......................................... C. incognita

2. Drupes elliptic ........................................... C. glazioviana

3. Rufescent branches; fruits pyriform ........... C. rufescens

3. Branches never rufescent; fruits (sub-) globose ............ 4

4. Flowers ca. $1.9 \mathrm{~cm}$; corolla lobes subtruncate; style ca. $1.1 \mathrm{~cm}$; stigma erect

C. trichotoma

4. Flowers ca. $4.6 \mathrm{~cm}$; corolla lobes orbicular; style ca. $9 \mathrm{~mm}$; stigma recurved

C. insignis

Cordia glazioviana (Taub.) Gottschling \& J.S. Mill., Syst. Bot. 31(2): 365 (2006).

Auxemma glazioviana Taub., Bot. Jahrb. Syst. 15(34): 11 (1892).

Selected material examined: BRAZIL. Bahia: Umburanas, Fazenda do Santo, 08-VII-2008, Santo 107 (HVASF).

Distribution: Endemic to Northeast Brazil associated to the Caatinga vegetation in the states of Ceará, Rio Grande do Norte, Pernambuco and Bahia (Melo \& al., 2014).

Cordia incognita Gottschling \& J.S. Mill., Syst. Bot. 31(2): 365 (2006).

Patagonula babiensis Moric., Pl. Nouv. Amer. 144: 86. 1847. Selected material examined: BRAZIL. Bahia: Sento

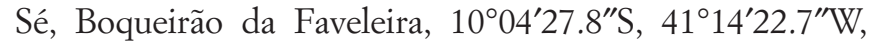
13-VIII-2006, Siqueira-Filho 1691 (HVASF).

Distribution: Endemic to the state of Bahia, Brazilian northeastern, where it is associated with areas of Caatinga vegetation (Melo \& al., 2014).

\section{Cordia insignis Cham., Linnaea 8: 122 (1833).}

Material examined: BRAZIL. Bahia: Sento Sé, Boqueirão

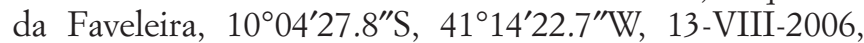
Siqueira-Filho et al. 1694 (HVASF).

Distribution: Occuring in Cerrado and dry forests from the western part of Bahía to central Bolivia up to $500 \mathrm{~m}$ in elevation (Miller, 2013). In Brazil, it occurs in the Northeast and Central-West regions associated to Cerrado vegetation (Taroda, 1984). In the northeast region it can be found in areas of Caatinga in the states of Rio Grande 

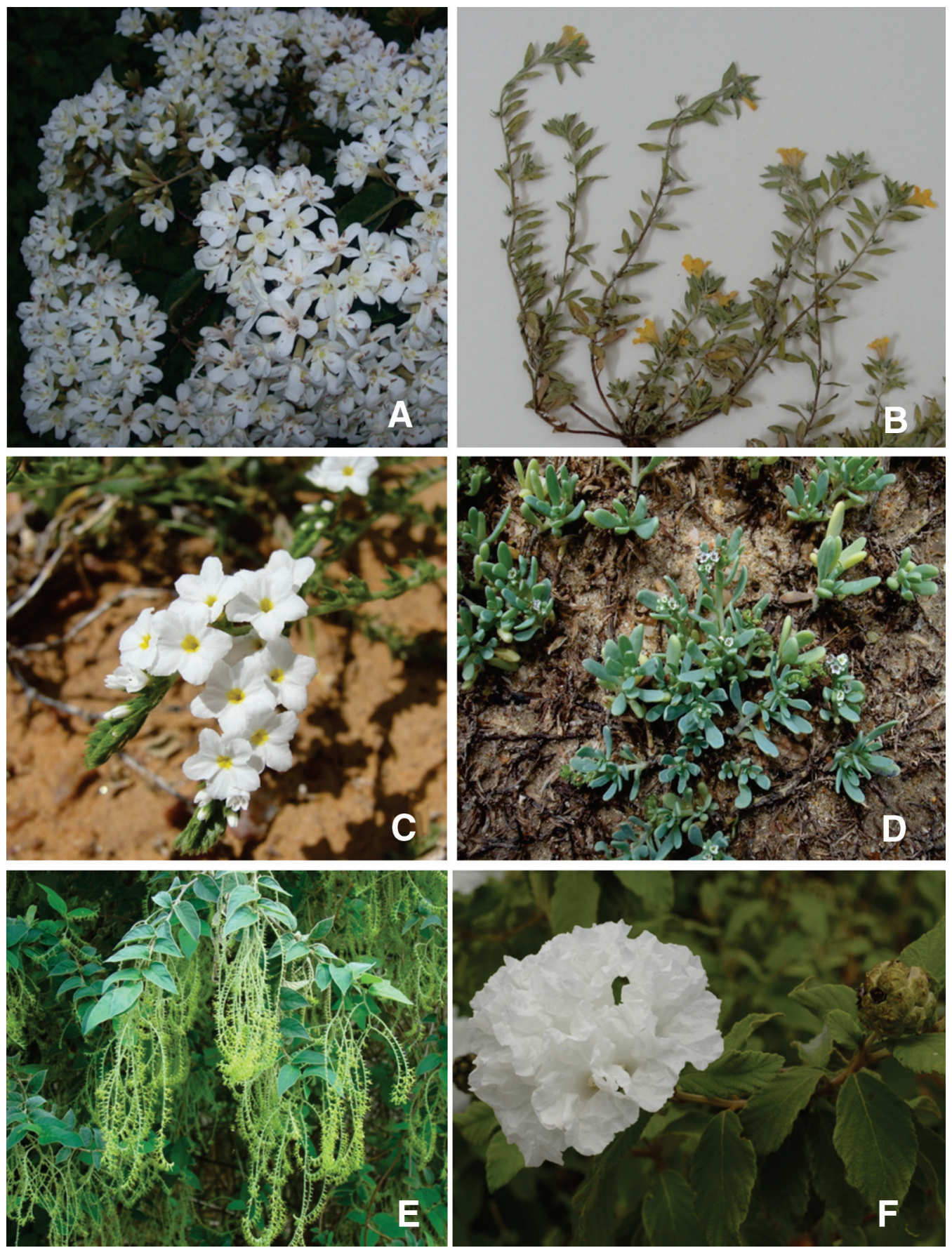

Fig. 2. Boraginaceae species of the study area, lower-mid and lower São Francisco River, Pernambuco and Bahia states, Northeast Brazil. A, Cordia trichotoma: inflorescence; B, Euploca paradoxa: habit; C, E. ternata: reproductive branch; D, Heliotropium curassavicum: habit; E, Myriopus salzmannii: habit; $\mathbf{F}$, Varronia leucocephala: reproductive branch, showing flowers and immature fruits.

do Norte (Taroda, 1984) and Alagoas and Sergipe (Melo $\&$ Sales, 2005).

Cordia rufescens A. DC., Prodr. 9: 476 (1845).

Material examined: BRAZIL. Bahia: São Desidério, Sítio Rio Grande, $12^{\circ} 26^{\prime} 30^{\prime \prime} \mathrm{S}, 45^{\circ} 09^{\prime} 50^{\prime \prime} \mathrm{W}, 12-\mathrm{VI}-2008$, Oliveira 3449 (HVASF).

Distribution: Endemic to Brazil where it occurs in the Northeast (Maranhão, Piauí, Ceará, Paraíba, Pernambuco, Alagoas, Bahia), Central-West (Goiás) and Southeast regions
(Minas Gerais), associated to Caatinga and Cerrado vegetation (Melo \& al., 2014).

Cordia trichotoma (Vell.) Arráb. ex Steud., Nom. ed. 2: 419 (1840). Fig. 2A

Cordiada trichotoma Vell., Fl. Flum. Icon. 2: 156 (1831). Selected material examined: BRAZIL. Bahia: Campo Alegre

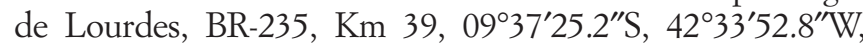
24 May 2009, Maciel et al. 1182 (HVASF); Glória, Complexo Itaparica, 14-VI-2007, Oliveira et al. 2814 (HVASF). 
Pernambuco: Custódia, ca. $24.5 \mathrm{~km}$ from Custódia, $08^{\circ} 21^{\prime} 45.2^{\prime \prime}$ S, 37 $50^{\prime} 19.4^{\prime \prime W}$, 07-VII-2009, Carvalho-Sobrinho 2254 (HVASF); São José do Belmonte, Sítio Tamboril, 07 46'08.7"S, 38 56'06.2"W, 18-VIII-2009, Fontana et al. 6101 (HVASF); Serrita, FLONA Negreiros, 0800'26.6"S,

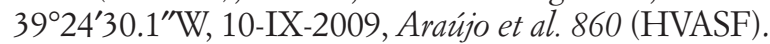

Distribution: Eastern Brazil extending south into parts of Bolivia, Paraguay and northern Argentina (Miller, 2013). In Brazil, it occurs throughout the Northeast and CentralWest, and in the Southeast (Minas Gerais, São Paulo, Rio de Janeiro) and South (Paraná) regions (Melo \& al., 2010). It is associated to Cerrado vegetation, including gallery forests, and more frequently in the Caatinga (Taroda, 1984; pers. obs.) and in the Amazon forest (Melo \& al., 2010).

Euploca Nutt., Trans. Amer. Philos. Soc. 5: 137. 1837.

\section{Key to the species}

1. Flowers solitary E. paradoxa

1. Flowers aggregated in scorpioid cymes ........................... 2

2. Inflorescences without bracts .......................................... 3

2. Inflorescences with bracts .............................................. 4

3. Corolla 3.5-5.5 mm; anthers strictly lanceolate; surface of the stigma setose E. barbata

3. Corolla $1.5-2 \mathrm{~mm}$; anthers ovate to ovate-lanceolate; surface of the stigma pubescent .............. E. procumbens 4. Corolla completely yellow ......................... E. polyphylla

4. Corolla white with yellow throat

5. Calyx never exceeding the middle portion of the corolla E. ternata

5. Calyx of equal length or slightly smaller than the corolla E. fruticosa

Euploca barbata (DC.) J.I.M. Melo \& Semir, Kew Bull. 64(2): 288 (2009).

Heliotropium barbatum DC., Prodr. 9: 541 (1845).

Material examined: BRAZIL. Bahia: Juazeiro/Bonfim, Km 38.5, 23-II-1983, Fotius 935 (CPATSA).

Distribution: Endemic to Northeast Brazil, occurring in the states of Pernambuco and Bahia associated to Caatinga vegetation in lowlands, and in the residual depressions of the São Francisco River (Melo \& Semir, 2010).

Euploca fruticosa (L.) J.I.M. Melo \& Semir, Kew Bull. 64(2): 288 (2009).

Heliotropium fruticosum L., Syst. Nat. 10: 913 (1759).

Material examined: BRAZIL. Pernambuco: Cabrobó, road from Terra Nova to Cabrobó, 08¹8'35.6"S, 39²2'12"W, 24-III-2009, Carvalho-Sobrinho 2052 (HVASF).

Distribution: Southern United States of America and the West Indies, reaching Venezuela and Brazil, where it has only been found in the state of Bahia in areas of Caatinga vegetation (Melo \& Semir, 2010).

Euploca paradoxa (Mart.) J.I.M. Melo \& Semir, Kew Bull. 64(2): 289 (2009). Fig. 2B

Preslaea paradoxa Mart., Nov. Gen. Sp. Pl. 2: 76 (1827).

Material examined: BRAZIL. Bahia: Casa Nova, Sítio Recanto, 09 $36^{\prime} 49.18^{\prime \prime S}$, 41 ${ }^{\circ} 16^{\prime} 44.77^{\prime \prime} \mathrm{W}, 13-\mathrm{I}-2008$, Pesqueira 32 (HVASF); Pernambuco: Cabrobó, $08^{\circ} 26^{\prime} 58^{\prime \prime} \mathrm{S}, 39^{\circ} 25^{\prime} 35^{\prime \prime} \mathrm{W}$, 22-I-2009, Maciel et al. 704 (HVASF); Petrolina, Fazenda
Experimental da UNIVASF, $09^{\circ} 19^{\prime} 05.75^{\prime \prime} \mathrm{S}, 40^{\circ} 33^{\prime} 05.75^{\prime \prime} \mathrm{W}$, 03-II-2009, Coelho 107 (HVASF).

Distribution: Endemic to Brazil, occurring in areas of Caatinga in the Northeast (Bahia, Paraíba, Pernambuco, Piauí) and Cerrado in the Central-West (Goiás, Mato Grosso), and recently recorded for the first time in the states of Paraíba, Pernambuco and Mato Grosso (Melo \& Semir, 2010).

Euploca polyphylla (Lehm.) J.I.M. Melo \& Semir, Kew Bull. 64(2): 289 (2009).

Heliotropium polyphyllum Lehm., Neue Schrift. Naturf. Ges. Halle 3(2): 9 (1817).

Material examined: BRAZIL. Pernambuco: Salgueiro, near to the reservoir on the way to Umãs, $08^{\circ} 05^{\prime} 47.2^{\prime \prime} \mathrm{S}$, $39^{\circ} 16^{\prime} 32.3^{\prime \prime} \mathrm{W}, 11-\mathrm{XI}-2008$, Maciel \& Carvalho-Sobrinho 607 (HVASF); Santa Maria da Boa Vista, Ilha de Inhanhuns, 15-IV-2008, Oliveira 3399 (HVASF).

Distribution: North and Central America, including the West Indies, and South America (as H. polyphyllum: Johnston, 1928). In Brazil it is dispersed along the Atlantic coast from Pará to Rio de Janeiro state associated to the coastal (Restinga) and Caatinga vegetation (Melo \& Semir, 2010).

Euploca procumbens (Mill.) Diane \& Hilger, Bot. Jahrb. Syst. 125(1): 48 (2003).

Heliotropium procumbens Mill., Gard. Dict. 8: 10 (1768). Selected material examined: BRAZIL. Pernambuco: Cabrobó, Reservatório Tucutu, lote 52, 08²8'11.1'S, $39^{\circ} 28^{\prime} 40.7^{\prime \prime} \mathrm{W}, 02-\mathrm{X}-2008$, Diniz et al. 10 (HVASF); Floresta, Bom Nome, $08^{\circ} 44^{\prime} 14.3^{\prime \prime} \mathrm{S}, 38^{\circ} 20^{\prime} 33.7^{\prime \prime} \mathrm{W}, 14-\mathrm{XI}-2008$, Ribeiro-Júnior et al. 08 (HVASF); Petrolândia, 08 41'55.8'S, $38^{\circ} 16^{\prime} 50.3^{\prime \prime} \mathrm{W}, 01-\mathrm{III}-2009$, Oliveira \& Luz 3850 (HVASF); Petrolina, UNIVASF, Fazenda Experimental, 09 $19^{\prime} 44.2^{\prime \prime}$, 40³3.1'30.1”W, 14-IX-2007, Pesqueira et al. 14 (HVASF); Salgueiro, Fazenda Negreiros, VPR Negreiros, $08^{\circ} 06^{\prime} 01.3^{\prime \prime} \mathrm{S}$, $39^{\circ} 11^{\prime} 01.3^{\prime \prime} \mathrm{W}, 20-\mathrm{I}-2009$, Maciel et al. 629 (HVASF); Santa Maria da Boa Vista, Ilha de Inhanhuns, 15-IV-2008, Oliveira 3398 (HVASF).

Distribution: From southern United States of America to Argentina (Fröhlich, 1981). In Brazil it is found in all regions (Melo \& Semir, 2010).

Euploca ternata (Vahl) J.I.M. Melo \& Semir, Kew Bull. 64(2): 289 (2009). Fig. 2C

Heliotropium ternatum Vahl, Symb. Bot. 3: 21 (1794). Selected material examined: BRAZIL. Bahia: Juazeiro, UNIVASF, Campus Juazeiro, 09'26'52.4"S, 40³1'34.2"W, 19-IV-2007, Agra et al. 09 (HVASF). Pernambuco: Floresta,

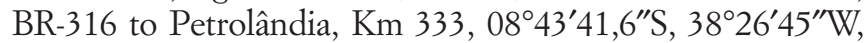
04-III-2009, Carvalho-Sobrinho et al. 2026 (HVASF); Petrolândia, on the section of the diversion canal, $08^{\circ} 41^{\prime} 15.4^{\prime \prime}$, $38^{\circ} 16^{\prime} 13.4^{\prime \prime} \mathrm{W}, 28-\mathrm{I}-2009$, Silva et al. 57 (HVASF); Terra Nova, on the way to Umãs, $08^{\circ} 12^{\prime} 54.3^{\prime \prime} \mathrm{S}, 39^{\circ} 21^{\prime} 12.1^{\prime \prime} \mathrm{W}$, 11-XII-2008, Maciel E Carvalho-Sobrinho 618 (HVASF).

Distribution: Mexico, West Indies, British Guiana, Venezuela and Brazil (as H. ternatum: Fröhlich, 1981), where it occurs in the Northeast (Bahia, Ceará, Paraíba, Pernambuco, Piauí, Rio Grande do Norte, Sergipe), CentralWest (Goiás) and Southeast (Minas Gerais) regions associated to all vegetation types (Melo \& al., 2014). 
Heliotropium L., Sp. Pl. 1: 130. 1753.

\section{Key to the species}

1. Petiole never partially winged; leaf blade fleshy; inflorescences few-flowered ............................ H. curassavicum

1. Petiole partially winged; leaf blade membranous; inflorescences multi-flowered

2. Corolla obcampanulate; fruit depressed-globose, verruculose $H$. angiospermum

2. Corolla hipocrateriform; fruit mitriform, costate

H. elongatum

Heliotropium angiospermum Murray, Prodr. Stirp. Götting.: 217 (1770).

Selected material examined: BRAZIL. Bahia: Curaçá, Fazenda Ouricuri, 09 $21^{\prime} 09.2^{\prime \prime} \mathrm{S}$, 39 36 $6^{\prime} 09.2^{\prime \prime} \mathrm{W}, 21$-IV2006, Siqueira-Filho et al. 1581 (HVASF); Glória, Complexo Itaparica, 24-XI-2006, Oliveira et al. 2513 (HVASF). Pernambuco: Floresta, BR-316 for Petrolândia, Km 333, $08^{\circ} 43^{\prime} 41.6^{\prime \prime} \mathrm{S}, 38^{\circ} 26^{\prime} 45^{\prime \prime} \mathrm{W}, 04-\mathrm{III}-2009$, Carvalbo-Sobrinho et al. 2016 (HVASF); Petrolândia, 28-I-2009, 0841'15.4"S, $38^{\circ} 16^{\prime} 13.4^{\prime \prime} \mathrm{W}$, Silva et al. 58 (HVASF); Salgueiro, Fazenda Miguel, 08 02'56.5"S, 39¹0'34.7"W, 09-II-2009, CarvalhoSobrinho et al. 1903 (HVASF).

Distribution: From the southern part of the United States of America to Brazil, including the West Indies (Fröhlich, 1981). In Brazil it is dispersed in the Northeast and Southeast regions associated to the Atlantic Forest and Caatinga vegetation (Melo \& Semir, 2008).

Heliotropium curassavicum L., Sp. Pl. 1: 130 (1753). Fig. 2D Material examined: BRAZIL. Pernambuco: Afrânio, Povoado de Caboclo, 08²8'28.2"S, 4056'11.6”W, 02-VI-2007, César et al. 05 (HVASF).

Distribution: Tropical regions of America, Africa and Asia. In Brazil it is found in the Northeast (Paraíba, Pernambuco) and South (Rio Grande do Sul) regions, associated to the Caatinga vegetation in saline habitats in the Northeast, and on stony soils in the South (Melo \& Semir, 2008).

Heliotropium elongatum (Lehm.) I.M. Johnst., Contr. Gray Herb. Harv. Univ. 81: 18 (1928).

Tiaridium elongatum Lehm. Pl. Asperif. Nucif. 16 (1818). Material examined: BRAZIL. Bahia: Casa Nova, Sítio Recanto, $09^{\circ} 36^{\prime} 49.18^{\prime \prime} \mathrm{S}, 41^{\circ} 16^{\prime} 44.77^{\prime \prime} \mathrm{W}, 15-\mathrm{I}-2008$, Pesqueira 38 (HVASF). Pernambuco: Petrolina, Fazenda Experimental UNIVASF, $09^{\circ} 19^{\prime} 05.2^{\prime \prime} \mathrm{S}, 40^{\circ} 33^{\prime} 05.2^{\prime \prime} \mathrm{W}, 11-\mathrm{X}-2008$, Ribeiro 09 (HVASF).

Distribution: South America, across Bolivia, Paraguay, Argentina, Uruguay and Brazil, where it occurs in the Northeast, Central-West, Southeast and South regions associated to all vegetation types except in the Amazon Forest (Melo \& Sales, 2004; Melo \& Semir, 2008).

Myriopus Small, Man. S.E. Fl.: 1131. 1933.

\section{Key to the species}

1. Calyx lacinia reaching the extremity of the corolla tube; fruits pubescent M. villosus

1. Calyx lacinia up to half of the corolla tube; fruits glabrous
2. Leaf blade concolorous; ovary obclavate; stigma subpeltate ...................................................... Mubicundus

2. Leaf blade discolorous; ovary conical-pyramidal; stigma strictly conical M. salzmannii

Myriopus rubicundus (Salzm. ex DC.) Luebert, Taxon 60(3): 677 (2011).

Tournefortia rubicunda Salzm. ex DC., Prodr. 9: 526 (1845).

Selected material examined: BRAZIL. Pernambuco: Afrânio, Fazenda Boqueirão, 08 25'32.3'S, 40 $54^{\prime} 15.4^{\prime \prime} \mathrm{W}$, 03-III-2007, Santo E Seido 44 (HVASF); Salgueiro, Fazenda Negreiros, $08^{\circ} 06^{\prime} 10^{\prime \prime} \mathrm{S}$, 39 $9^{\circ} 10^{\prime} 49^{\prime \prime} \mathrm{W}, 22-\mathrm{I}-2009$, Maciel et al. 724 (HVASAF); Santa Maria da Boa Vista, Ilha de Inhanhuns, 15-IV-2008, Oliveira 3388 (HVASF).

Distribution: Bolivia, Paraguay, Argentina and Brazil, where it extends from Pernambuco and Mato Grosso to Rio Grande do Sul state (as T. rubicunda: Johnston, 1930; Cavalheiro \& al., 2011).

Myriopus salzmannii (DC.) Diane \& Hilger, Bot. Jahrb. Syst. 125(1): 47 (2003). Fig. 2E

Tournefortia salzmannii DC., Prodr. 9: 524 (1845).

Examined material selected: BRAZIL. Pernambuco: Afrânio, Fazenda Boqueirão, 08 $29^{\prime} 11.3^{\prime \prime} \mathrm{S}, 40^{\circ} 55^{\prime} 49.8^{\prime \prime} \mathrm{W}$, 03-VI-2007, Oliveira et al. 39 (HVASF); Salgueiro, BR-116, $07^{\circ} 59^{\prime} 42.3^{\prime \prime} \mathrm{S}, 39^{\circ} 07^{\prime} 42.3^{\prime \prime} \mathrm{W}, 31-\mathrm{III}-2009$, Carvalho-Sobrinho E Rodrigues 2099 (HVASF).

Distribution: Argentina, Paraguay, Bolivia and Brazil, where it is dispersed in the Northeast, Southeast and South regions (as T. salzmannii: Cavalheiro \& al., 2011).

Myriopus villosus (Salzm. ex DC.) J.I.M. Melo, comb. nov. TYPE: [Brazil: Bahia], 1830, Salzmann 369 (lectotype, G[147254!]; isotypes, FM!, GH!, K!, P!, RB!).

Tournefortia villosa Salzm. ex DC., Prodr. 9: 524 (1845).

Additional material examined:BRAZIL. Bahia:Umburanas,

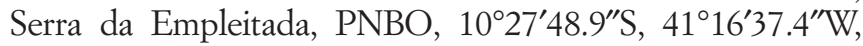
21-IX-2006, Siqueira-Filho et al. 1753 (HVASF).

Distribution: Endemic to Brazil, occuring in the Northeast (Maranhão, Piauí, Bahia), Southeast (Minas Gerais, Espírito Santo, São Paulo, Rio de Janeiro) and South (Paraná) regions, associated with Amazon, Caatinga, Cerrado and Atlantic Forest (as T. villosa: Melo \& al., 2010; Cavalheiro \& al., 2011).

Comments: Following Johnston (1930), T. villosa belongs to Tournefortia sect. Cyphocyema I.M. Johnst. by the characteristic structures of its fruit. According to the same author (1930), it is four-lobed and composed of four cosimilar distinct nutlets surrounded and bound together by an epicarp that is frequently juicy. The embryo is evidently curved and in addition to these fruit-structures the species of section Cyphocyema are characterized by the very narrow elongate corolla-lobes with involute margins and the subvalvate arrangement in the bud. Based on these characters the accommodation of T. villosa in the genus Myriopus is inevitable and the new combination it is being proposed here.

Varronia P. Browne, Civ. Nat. Hist. Jamaica: 172. 1756.

\section{Key to the species}

1. Inflorescences spikes V. curassavica

1. Inflorescences capitate 2 
2. Leaf blade markedly discolorous ........ V. leucomalloides

2. Leaf blade slightly discolorous ... 3

3. Calyx lacinia with cirrose apex; corolla $2.5-3.5 \mathrm{~mm}$....

V. globosa

3. Calyx lacinia with acute apex; corolla $13-34 \mathrm{~mm}$......... V. leucocephala

Varronia curassavica Jacq., Enum. Syst. Pl.: 14 (1760).

Cordia curassavica (Jacq.) Roem. \& Schult., Syst. Veg., ed. 15 bis 4: 460 (1819).

Material examined: BRAZIL. Pernambuco: Santa Cruz, Fazenda Água Pobre, $08^{\circ} 15^{\prime} 06.56^{\prime \prime} \mathrm{S}, 40^{\circ} 23^{\prime} 06.56^{\prime \prime}$, 20-X-2008, Xavier et al. 02 (HVASF).

Distribution: From northern Mexico to northeastern South America, including the West Indies (as C. curassavica: Miller, 1988). In Brazil it is dispersed in all regions, associated with Cerrado, Restinga and forest environments (Melo \& al., 2014).

Varronia globosa Jacq., Enum. Syst. Pl.: 14 (1760).

Cordia globosa Kunth, Nov. Gen. Sp. 3: 76.

Selected material examined: BRAZIL. Pernambuco: Custódia, road to 'lote 11', 14-V-2009, Carvalho-Sobrinho et al. 2207 (HVASF). Petrolândia, BR-316 for Floresta, 03-III-2009, Carvalho-Sobrinho et al. 2004 (HVASF).

Distribution: From southeast Florida to the northeastern portion of South America, including the West Indies (as C. globosa: Miller, 1988). According to Melo \& al. (2014), in Brazil it occurs only in the Northeast region (Ceará, Rio Grande do Norte, Paraíba, Pernambuco, Alagoas, Sergipe, Bahia) associated to the Caatinga vegetation.

Varronia leucocephala (Moric.) J.S. Mill., Novon 17(3): 374 (2007). Fig. 2F

Cordia leucocephala Moric., Pl. Nouv. Amer. 9: 148 (t. 88) (1847).

Material examined: BRAZIL. Bahia: Curaçá, Fazenda Ouricuri, 09²1'09.2"S, 39³6'09.2"WW, 22-IV-2006, SiqueiraFilho 1599 (HVASF). Pernambuco: Afrânio, Povoado de Caboclo, Fazenda Boqueirão, 08 27'58.7'S, 40 $55^{\prime} 22.2^{\prime \prime} \mathrm{W}$, 18-III-2006, Santo et al. 15 (HVASF).

Distribution: Endemic to Brazil where it occurs in Northeast region (Melo \& al., 2014), associated with Caatinga vegetation (Taroda, 1984; Melo \& Sales, 2005) and Restinga (Melo \& Sales, 2005), treated under C. leucocephala.

Varronia leucomalloides (Taroda) J.S. Mill., Novon 17(3): 374 (2007).

Cordia leucomalloides Taroda, Notes Roy. Bot. Gard. Edinburgh 44: 125(-128) (1986).

Material examined: BRAZIL. Bahia: Gentio do Ouro, Serra de Sapé, $11^{\circ} 11^{\prime} 07.4^{\prime \prime S}, 42^{\circ} 43^{\prime} 07.4^{\prime \prime} \mathrm{W}, 26-\mathrm{V}-2009$, Siqueira-Filho et al. 2059 (HVASF).

Distribution: Endemic to northeastern Brazil, occurring in the states of Ceará, Paraíba and Bahia associated with Caatinga and Cerrado vegetation (Melo \& al., 2014).

\section{ACKNOWLEDGEMENTS}

The author thanks to Dr. Leonor Costa Maia of the Virtual Herbarium of the Flora and Fungi - National Institutes of Science and Technology (INCT), for providing financial assistance to visits to the herbaria of Petrolina, Pernambuco state, Brazil, to CNPq (Conselho Nacional de
Desenvolvimento Científico e Tecnológico) the Productivity Research fellowship (PQ-2), to Jean P. Costa and Manoel Jeovani P. Costa for preparation of the map of the São Francisco River. The author is also grateful to an anonymous reviewer; to Dr. Gonzalo Nieto Feliner, associate editor; and to Dr. Federico Luebert, University of Bonn, Germany, for their valuable suggestions which improved this paper.

\section{REFERENCES}

Albach, D.C., Soltis, P.S., Soltis, D.F. \& Olmstead, R.G. 2001. Phylogenetic analysis of asterids based on sequences of four genes. Annals of the Missouri Botanical Garden 88: 163-212. http://dx.doi.org/10.2307/2666224

Angiosperm Phylogeny Group. 1998. An ordinal classification for the families of flowering plants. Annals of the Missouri Botanical Garden 85: 531-553. http://dx.doi.org/10.2307/2992015

Angiosperm Phylogeny Group II. 2003. An update of the Angiosperm Phylogeny Group classification for the orders and families of flowering plants: APG II. Botanical Journal of the Linnean Society 141: 399-436. http://dx.doi.org/10.1046/j.1095-8339.2003.t01-1-00158.x

Angiosperm Phylogeny Group III. 2009. An update of the Angiosperm Phylogeny Group classification for the orders and families of flowering plants. Botanical Journal of the Linnean Society 161: 105-121. http:// dx.doi.org/10.1111/j.1095-8339.2009.00996.x

Bentham, G. \& Hooker, J.H. 1873-1876. Boragineae. In: Bentham, G. \& Hooker, J.H. (eds.), Genera Plantarum 2: 832-865. Lovell Reeve \& Co., Edinburgh.

Böhle, U.R. \& Hilger, H.H. 1997. Chloroplast DNA systematics of "Boraginaceae" and related families: a goodbye to the old familiar concept of 5 subfamilies. Scripta Botanica Belgica 15: 30.

Bremer, B., Bremer, N., Heidari, N., Erixon, P., Olsmtead, R.G., Anderberg, A.A., Kollersj, M. \& Barkhordarian, E. 2002. Phylogenetics of asterids based on 3 coding and 3 non-coding chloroplast DNA markers and the utility of non-coding DNA at higher taxonomic levels. Molecular Phylogenetics and Evolution 24: 274-301. http://dx.doi.org/10.1016/ S1055-7903(02)00240-3

Candolle, A.P. de. 1845. Boraginaceae. In: A.P. De Candolle (ed.), Prodromus Systematis Naturalis Regni Vegetabilis 9: 466-559. Treuttel \& Würtz, Paris.

Cavalheiro, L., Ranga, N.T. \& Furlan, A. 2011. Tournefortia L. (Boraginaceae): espécies do Brasil extra-amazônico. Hoehnea 38: 221-242. http://dx.doi org/10.1590/S2236-89062011000200004

Dalla Torre, C.G. \& Harms, H. 1900. Borraginaceae. In: Genera siphonogarum: Systema Englerianum Conscripta: 424-429. Suntibus Guilelm Engelmann, Lipsiae.

Diane, N., Förther, H. \& Hilger, H.H. 2002a. A systematic analysis of Heliotropium, Tournefortia, and alliex taxa of the Heliotropiaceae (Boraginales) based on ITS1 sequences and morphological data. American Journal of Botany 89: 287-295. http://dx.doi.org/10.3732/ ajb.89.2.287

Diane, N., Hilger, H.H. \& Gottschling, M. 2002b. Transfer cells in the seeds of Boraginales. Botanical Journal of the Linnean Society 140: 155-164. http://dx.doi.org/10.1046/j.1095-8339.2002.00085.x

Diane, N., Jakob, C. \& Hilger, H.H. 2003. Comparative leaf anatomy and distribution of foliar trichome types in Heliotropiaceae. Flora 198: 1-18. http://dx.doi.org/10.1078/0367-2530-00120

Förther, H. 1998. Die infragenerische Gliederung der Gattung Heliotropium L. und ihre Sterllung innerhalb der subfam. Heliotropioideae (Schrad.) Arn. (Boraginaceae). Sendtnera 5: 35-241.

Fresenius, G. 1857-1863. Cordiaceae, Heliotropieae et Borragineae. In Martius, C.F.P. (ed.), Flora Brasiliensis 9(3): 1-60. F. Fleischer, Lipsiae.

Frigoletto. 2011. A bacia do rio São Francisco. http://www.frigoletto.com. br/GeoFis/Bacias/baciasfranc.html (accessed 15 Aug 2014).

Fröhlich, M.W. 1981. Heliotropium. In: Nash, D.L. \& Moreno, N.P. (eds.), Boraginaceae. Flora de Vera Cruz 18: 70-84. Instituto Nacional de Investigaciones sobre Recursos Bioticos, Xalapa.

Gottschling, M., Hilger, H.H., Wolf, M. \& Diane, N. 2001. Secondary structure of the ITS1 transcription and its application in a reconstruction of the phylogeny of Boraginales. Plant Biology 3: 629-636. http:// dx.doi.org/10.1055/s-2001-19371

Gottschling, M., Miller, J.S., Weigend, M. \& Hilger, H.H. 2005. Congruence of a phylogeny of Cordiaceae (Boraginales) inferred from ITS1 sequence data with morphology, ecology, and biogeography. Annals of the Missouri Botanical Garden 92: 425-437.

Gürke, M. 1893. Boraginaceae. In: Engler, A. \& Prantl, K. (eds.), Die natürlichen Pflanzenfamilien IV(3): 49-96. Wilhelm Engelmann, Leipzig. 
Hickey, L.J. 1973. Classification of the architecture of dicotyledonous leaves. American Journal of Botany 60: 17-33. http://dx.doi.org/10.2307/2441319

Hilger, H.H. \& Diane, N. 2003. A systematics analysis of Heliotropiaceae (Boraginales) based on $\operatorname{trn} \mathrm{L}$ and ITS1 sequence data. Botanische Jabrbücher für Systematik, Pflanzengeschichte und Pflanzengeographie 125: 19-51. http://dx.doi.org/10.1127/0006-8152/2003/0125-0019

Johnston, I.M. 1928. Studies in Boraginaceae 7: The South American species of Heliotropium. Contributions from the Gray Herbarium of Harvard University 81: 3-73.

Johnston, I.M. 1930. Studies in Boraginaceae 8: Observations on the species of Cordia and Tournefortia known from Brazil, Paraguay, Uruguay and Argentina. Contributions from the Gray Herbarium of Harvard University 82: 3-89.

Judd, W.S., Campbell, C.S., Kellogg, E.A. \& Stevens, P.F. 1999. Plant systematics: A phylogenetic approach. Sinauer Associates Inc., Sunderland.

Luebert, F. 2013. A revision of Heliotropium sect. Cochranea (Heliotropiaceae). Kew Bulletin 68: 1-54. http://dx.doi.org/10.1007/s12225-013-9432-6

Luebert, F., Brokamp, G., Wen, J., Weigend, M. \& Hilger, H.H. 2011a. Phylogenetic relationships and morphological diversity in Neotropical Heliotropium (Heliotropiaceae). Taxon 60: 663-80.

Luebert, F. \&. Hilger, H.H. 2014. Typification of Heliotropium and Tournefortia (Heliotropiaceae) species described by Ruiz and Pavón. Anales del Jardín Botánico de Madrid: e012. http://dx.doi.org/10.3989/ajbm.2332

Luebert, F., Hilger, H.H. \& Weigend, M. 2011b. Diversification in the Andes: Age and origins of South American Heliotropium lineages (Heliotropiaceae, Boraginales). Molecular Phylogenetics and Evolution 61: 90-102. http://dx.doi.org/10.1016/j.ympev.2011.06.001

Luebert, F. \& Wen, J. 2008. Phylogenetic analysis and evolutionary diversification of Heliotropium sect. Cochranea (Heliotropiaceae) in the Atacama Desert. Systematic Botany 33: 390-402. http://dx.doi.org/ $10.1600 / 036364408784571635$

Melo, J.I.M. \& Lyra-Lemos, R.P. 2008. Sinopse taxonômica de Boraginaceae s.l. A. Juss. no estado de Alagoas - Brasil. Acta Botanica Brasilica 22: 701-710. http://dx.doi.org/10.1590/S0102-33062008000300008

Melo, J.I.M. \& Sales, M.F. 2004. Heliotropium L. (BoraginaceaeHeliotropioideae) de Pernambuco, Nordeste do Brasil. Rodriguésia 55 65-87.

Melo, J.I.M. \& Sales, M.F. 2005. Boraginaceae A. Juss. na região de Xingó: Alagoas e Sergipe. Hoebnea 32: 369-380.

Melo, J.I.M. \& Semir, J. 2008. Taxonomia do gênero Heliotropium L. (Heliotropiaceae) no Brasil. Acta Botanica Brasilica 22: 754-770. http:// dx.doi.org/10.1590/S0102-33062008000300013

Melo, J.I.M. \& Semir, J. 2010. Taxonomia do gênero Euploca Nutt. (Heliotropiaceae) no Brasil. Acta Botanica Brasilica 24: 111-132. http:// dx.doi.org/10.1590/S0102-33062010000100012
Melo, J.I.M., Silva, L.C., Stapf, M.N.S. \& Ranga, N.T. 2010. Boraginaceae. In: Forzza, R.C. \& al. (eds.), Catálogo de Plantas e Fungos do Brasil: 773-777. Instituto de Pesquisas Jardim Botânico do Rio de Janeiro, Rio de Janeiro.

Melo, J.I.M., Cavalheiro, L., Stapf, M.N.S. \& Vieira, D.D. 2014 Boraginaceae. In: Forzza, R.C. \& al. (orgs.), Lista de Espécies da Flora do Brasil. http://floradobrasil.jbrj.gov.br/jabot/floradobrasil/FB64 (accessed 16 Aug 2014).

Miller, J.S. 1988. A revised treatment of Boraginaceae for Panamá. Annals of the Missouri Botanical Garden 75: 456-521. http://dx.doi. org $/ 10.2307 / 2399433$

Miller, J.S. 2013. A revision of Cordia section Gerascanthus (Boraginales: Cordiaceae). Journal of the Botanical Research Institute of Texas 7:55-83.

Payne, W.W. 1978. A glossary of plant hair terminology. Brittonia 30: 239-255. http://dx.doi.org/10.2307/2806659

Radford, A.E., Dickison, W.C., Massey, J.R. \& Bell, C.R. 1974. Vascular Plant Systematics. Harper \& Row Publisher, New York.

Rizzini, C.T. 1977. Sistematização terminológica da folha. Rodriguésia 29: 103-125.

Soltis, P.S., Soltis, D.E., Savolainen, V., Crane, P.R. \& Barraclough, T.G. 2002. Rate heterogeneity among lineages of tracheophytes: integration of molecular and fossil data and evidence for molecular living fossils. Proceedings of the National Academy Sciences of the United States of America 99: 4430-4435. http://dx.doi.org/10.1073/pnas.032087199

Taroda, N. 1984. Taxonomic studies on Brazilian species of Cordia (Boraginaceae). Thesis. University of Saint Andrews, Saint Andrews.

Taroda, N. \& Gibbs, P.E. 1986a. Studies on the genus Cordia L. (Boraginaceae) in Brazil. 1. A new infrageneric classification and conspectus. Revista Brasileira de Botânica 9: 31-42.

Taroda, N. \& Gibbs, P.E. 1986b. A revision of the Brazilian species of Cordia subgenus Varronia (Boraginaceae). Notes from the Royal Botanical Gardens of Edinburgh 44: 105-140.

Taroda, N. \& Gibbs, P.E. 1987. Studies on the genus Cordia L. (Boraginaceae) in Brazil. 2. An outline taxonomic revision of subgenus Myxa Taroda. Hoebnea 14: 31-52.

Thiers, B. 2012. Index herbariorum: a global directory of public herbaria and associated staff. http://sciweb.nybg.org/science2/IndexHerbariorum.asp (accessed 19 Aug 2014).

W $^{3}$ Tropicos. 2014. Missouri Botanical Garden. http://www.tropicos.org (accessed 11 Aug 2014).
Associate Editor: Gonzalo Nieto Received: 27-X-2014 Accepted: 22-I-2015 